IZA DP No. 7143

Early to Bed and Earlier to Rise: School, Maternal Employment, and Children's Sleep

Jay Stewart

January 2013 


\title{
Early to Bed and Earlier to Rise: School, Maternal Employment, and Children's Sleep
}

\author{
Jay Stewart \\ U.S. Bureau of Labor Statistics \\ and IZA \\ Discussion Paper No. 7143 \\ January 2013
}

IZA

P.O. Box 7240

53072 Bonn

Germany

Phone: +49-228-3894-0

Fax: +49-228-3894-180

E-mail: iza@iza.org

Any opinions expressed here are those of the author(s) and not those of IZA. Research published in this series may include views on policy, but the institute itself takes no institutional policy positions. The IZA research network is committed to the IZA Guiding Principles of Research Integrity.

The Institute for the Study of Labor (IZA) in Bonn is a local and virtual international research center and a place of communication between science, politics and business. IZA is an independent nonprofit organization supported by Deutsche Post Foundation. The center is associated with the University of Bonn and offers a stimulating research environment through its international network, workshops and conferences, data service, project support, research visits and doctoral program. IZA engages in (i) original and internationally competitive research in all fields of labor economics, (ii) development of policy concepts, and (iii) dissemination of research results and concepts to the interested public.

IZA Discussion Papers often represent preliminary work and are circulated to encourage discussion. Citation of such a paper should account for its provisional character. A revised version may be available directly from the author. 


\section{ABSTRACT \\ Early to Bed and Earlier to Rise: School, Maternal Employment, and Children's Sleep*}

School-age children need 10-11 hours of sleep per night. It has been well-documented that lack of sleep leads to diminished cognitive performance and that people who sleep less are more likely to be overweight or obese. I use data from the American Time Use Survey (ATUS) to examine two factors that can potentially influence the amount of time children sleep: school and maternal employment. I find that school-age children sleep less when school is in session than during the summer, and that they get less sleep on school nights than on non-school nights. Children go to bed about 38 minutes earlier on school nights, but wake up about 72 minutes earlier on school days. This translates into about 34 minutes less sleep on school nights compared with non-school nights, and implies that these children have a cumulative sleep deficit of over two-and-a-half hours by the time they arrive at school Friday morning. In addition to the lost sleep time, the earlier wake-up times on school days appear to disrupt children's natural sleep cycles. Maternal employment affects children's sleep time in the summer, because children wake up earlier on days that their mothers work. But during the school year, maternal employment effects are dominated by school effects.

JEL Classification: J22

Keywords: $\quad$ sleep, school start times, maternal employment, time use

Corresponding author:

Jay Stewart

U.S. Bureau of Labor Statistics

2 Massachusetts Ave., NE

Washington, DC 20212

USA

E-mail: Stewart.Jay@bls.gov

\footnotetext{
*I thank Harley Frazis, Sabrina Pabilonia, and three anonymous referees for their helpful comments. Any views expressed in this paper do not necessarily reflect those of the Bureau of Labor Statistics.
} 


\section{Introduction}

School-age children need a lot of sleep—between 10 and 11 hours each night. ${ }^{1}$ Sleep is important for children’s cognitive development and their general health, and it has been welldocumented that lack of sleep leads to diminished cognitive performance and that people who sleep less are more likely to be overweight or obese (Gangwisch et al. 2005). Although there is relatively little research on the effects of sleep loss on school-age children, the studies that have been conducted have found that sleep loss is detrimental.

An experimental study by Fallone et al. (2005) systematically varied the amount of time that children slept each night, and then obtained reports from their teachers. These researchers found that attention problems increased and academic performance decreased when children got less sleep. Another study (Epstein et al. 1998) found that children who started school earlier (and who got less sleep) were more likely to be sleepy and have difficulty concentrating during school compared with children who started later.

In this study, I examine two factors_-school and maternal employment—-that can potentially affect the amount of time that school-age children sleep. A large literature has examined the effect of school start times on the academic performance of high school students, ${ }^{2}$ but the Epstein et al. (1998) study is the only one that examines the effect on younger students. Earlier school start times can adversely affect school performance if children get less sleep or if their normal sleep patterns (which are regulated by the release of melatonin) are disrupted because they have to wake up earlier. Maternal employment can affect children's sleep time if children

\footnotetext{
${ }^{1}$ This is the National Sleep Foundation recommendation for children ages 5-12 (http://www.sleepfoundation.org/article/sleep-topics/children-and-sleep).

2 See Carrell, Maghakian, and West (2011) for a nice summary of this literature.
} 
stay up later to spend time with their parents after work or wake up earlier to be taken to beforeschool care or summer camp before their mothers go to work.

An examination of the effect of school on the sleep patterns of school-age students potentially has implications for school districts’ policies on start times. So far, most of the research on school start times has focused on high school students. Although high school students need less sleep than younger children, their biological clocks are such that they prefer afternoons and evenings to mornings. Thus the early start times of many high schools conflict with teenagers' natural tendency to stay up late and then sleep-in in the morning. ${ }^{3}$ There is evidence that the "delayed phase” sleep of adolescents is due more to biological rather than social factors, ${ }^{4}$ which suggests that teens do not compensate for early school start times by going to bed earlier. Thus, the effects of the later start time on academic performance can come through two channels: (1) teens get more sleep and (2) the timing of their sleep is more compatible with their biological clocks. The latter suggests that allowing teens to sleep later should improve academic performance even if they do not get any additional sleep. If we observe that school-age children sleep less because they wake up earlier on school days, then school systems may want to reassess school start times for these students as well.

There has been relatively little research on the effect of maternal employment on children's sleep patterns, but there are at least two good reasons to study this. First, if children of employed mothers sleep less, then sleep is a possible mechanism by which maternal employment affects child outcomes. ${ }^{5}$ Most of the research on mechanisms has used time-diary data to analyze the

\footnotetext{
${ }^{3}$ As a result of this body of research, some school districts have pushed back high school start times.

${ }^{4}$ Crowley, Acebo, and Carskadon (2007) and Carskadon, Viera, and Acebo (1993),

${ }^{5}$ The evidence on the effect of maternal employment on child outcomes is somewhat mixed, but most studies find negative effects. Baum (2003) and Ruhm (2004) find negative effects on cognitive development, while JamesBurdumy (2005) finds positive effects. Other studies have found positive associations between maternal
} 
amount of time parents spend in activities that are thought to affect child outcomes. Cawley and Liu (2007a) find that employed parents spend less time helping their children with homework and in other educational activities. And Stewart (2010) finds that full-time employed mothers of pre-school-age children shift enriching childcare activities to times that are later in the day, when children are more tired and less able to benefit from those activities. ${ }^{6}$ Second, if mothers' employment does affect their children's sleep times during the school year, then later school start times may not benefit the children of employed mothers. If the children of working mothers are dropped off at before-school care on their way to work, then later start times will not result in these children getting more sleep. Instead they would simply spend more time in before-school care.

The research conducted to date suggests that children with employed mothers do sleep less. Hofferth and Sandberg (2001) used the Child Development Supplement (CDS) to the Panel Study of Income Dymanics (PSID) to examine how much time children spend in various activities. Although their study did not focus on sleep, their regressions showed that that children with employed mothers slept less than children whose mothers did not work. A study by Hale et al. (2009) examined the determinants of bed time routines. These authors focused mainly on the demographic characteristics of household members, but also included a variable for maternal employment. The coefficient on that variable indicated that pre-school age children with working mothers went to bed later than children whose mothers did not work, although the effect was rather small and only marginally significant.

employment and the incidence of injuries and infectious disease (Gordon, Kaestner, and Korenman, 2007), and obesity (Anderson, Butcher, and Levine, 2003).

${ }^{6}$ Other papers, by Cawley and Liu (2007b) and Fertig, et al (2010) have examined the mechanisms by which maternal employment might lead to child obesity. They focus mainly on the reduction in time spent preparing meals at home, which implies that children are eating more prepared foods (prepackaged or restaurant food). 
This study fills several voids. It is the first study that I am aware of to examine the effects of school and maternal employment on the sleep time of school-age children. In addition to looking at the total amount of time that children sleep, I look at wake-up and bed times because policy implications may be different depending on whether children lose sleep in the morning or the evening. If children lose sleep on school days because they wake up earlier, then school districts may want to reexamine their start times. But if the effect is in the evening, then it may be more appropriate to look at homework policies. The studies that examine maternal employment and child sleep consider only total sleep time (Hofferth and Sandberg, 2001) or bed times (Hale et al. 2009). By examining both wake-up and bed times, I can get a clearer picture of employment (and school) effects. I also allow for the possibility that the effect of maternal employment may be different in the summer than during the school year. It is important to distinguish between the school year and the summer, because it is possible that any effect of maternal employment on sleep is overshadowed by school effects. But even if school is the dominant influence, mothers' work schedules may limit the benefit that students might receive from adjusting school start times.

The rest of the paper proceeds as follows. In the next section, I describe my data, and take a first look at school children's sleep patterns. Next, I estimate the effect of school and maternal employment on children's sleep time. I identify the school effect by comparing school days (nights) to non-school days (nights) during the school year. Whether a day is a school day is clearly exogenous, but it is possible that children sleep longer on weekends to make up for sleep lost during the school week. Because this would bias my estimates, I examine the validity of using non-school days (nights) during the school year as a control by considering other possible comparisons. I make a similar comparison to examine the effects of maternal employment on 
children's sleep. Here the case for exogeneity is less clear. Mothers clearly choose whether or not to work and likely have some control over their work schedules (at least ex ante). But the maternal employment decision can plausibly be considered to be exogenous if their children's sleep patterns are not a key consideration. The final section concludes.

\section{Data}

I used data from the 2003-2010 American Time Use Survey (ATUS), which collects detailed time diaries from individuals age 15 and older. ${ }^{7}$ Although the ATUS does not collect time diaries from household members under 15 years of age, it does collect information about when children under 13 woke up and went to bed. Specifically, as part of the collection of information on secondary childcare, the ATUS asks respondents when the first child under 13 woke up and when the last child under 13 went to sleep. ${ }^{8}$ If there are two or more children under 13 in the household, then it is not possible to make any inferences about how much sleep any one child gets. But by restricting my sample to the time diaries of mothers in households with only one child under 13, I know when that child woke up and went to bed. I restricted the sample to mothers' diaries, because fathers' diaries do not have any information on whether the mother worked on the diary day. Throughout the paper I treat the child as the unit of analysis, even though it is the mother's time diary that is the source of the data. All estimates are generated using the mothers' sample weights.

\footnotetext{
${ }^{7}$ See Hamermesh, Frazis, and Stewart (2005) and Frazis and Stewart (2007) for details about the ATUS.

8 These questions were added to the survey, because cognitive testing revealed that respondents were not consistent in reporting secondary childcare at times when their children were asleep (some parents reported this time, while others did not). To ensure consistency across respondents, the ATUS asks the wake and sleep times and excludes any secondary childcare that was reported when all children under 13 were asleep. The ATUS does not ask about naps, which means that reported secondary childcare time includes times when children are napping.
} 
The ATUS data allow me to examine the sleep time of school-age children with a sample that is much larger than the PSID’s Child Development Supplement, which is often used to examine the time use of young children. However, there are several caveats to using the ATUS's wake-up and bed time data. First, like any data that rely on parents' reports, I do not know what time the child actually woke up in the morning or went to sleep at night. Children might stay up and read after they have been put to bed by their parents. Similarly, they may read or play electronic games before their parents know they are awake. This means that these times likely overestimate the amount of sleep that children get. However, as long as the relationship between reported and actual sleep times do not vary too much with the variables in the regression equations, this reporting problem should not affect the marginal effects reported here. Second, these questions allow me to determine the amount of time that the child spent awake on the diary day, which is not the same as being able to observe completed sleep spells. However, by looking at wake-up and bed times separately, it is possible to make inferences about the amount of time that children sleep on school and non-school nights. Third, because it is necessary for me to restrict my sample to mothers with only one child under 13, the results may not generalize. Most of the children in the sample are either the youngest child (those with older siblings) or an only child (those with no older siblings). Note that the oldest children in the sample are much more likely to be the youngest children in their families (i.e., have older siblings). ${ }^{9}$ Thus, it is not possible to examine birth order effects, although I do control for the presence of older siblings.

I did not place any sample restrictions on the age of the mothers, but I did restrict the sample based on the age of the child. I excluded children under 5 from the analysis because many of these children still take naps, which are not recorded in the time diaries. And I excluded 5 year-

\footnotetext{
${ }^{9}$ The percentages of 6-8, 9-10, and 11-12 year-olds with older siblings are 36, 50, and 60, respectively.
} 
olds, because there is no way to know whether they are in school. Finally, I restricted the sample to children in two types of family arrangements—children whose parents are married and whose fathers work, and children of single mothers — because there are very few children in the other arrangements, which are likely to be quite different. ${ }^{10}$

The top panel of Table 1 shows how time spent awake (awake time) varies by age of child and day of week. The sample includes both summer and school-year observations (defined below). The results are as one might expect. Awake time increases as children get older, from 13.9 hours per day for 6-8 year-olds to 14.5 hours for 11-12 year-olds. The other notable pattern is that children are awake longer on weekdays, with the weekday-weekend difference increasing as children get older. All of these differences are statistically significant at the 5-percent level (most are significant at the 1-percent level), except the weekend comparison of 9-10 year-olds and 11-12 year-olds. Note that this table implies that 6-8 year-old children get just over 10 hours of sleep per night, which is at the low end of the 10-11 hours of sleep that is recommended. Children in the 11-12 age group average less than 10 hours of sleep per night.

The two lower panels of Table 1 show wake-up and bed times by age of child and day of week. The time is in decimal form so that 7.25 is 7:15. For bedtimes in the lower panel, I redefined weekdays to be Sunday through Thursday and weekends to be Friday and Saturday. There are several things to note about wake-up times. First and not surprisingly, children wake up later on weekends, and the weekend-weekday difference in wake-up times is greater for older children, with all of the differences being statistically significant at the 5-percent level. Second, the differences in average weekday wake-up times between age groups are small and none is statistically significant. On weekends, children wake up later as they get older. The lower panel

${ }^{10}$ There were only 172 children with married parents and a non-employed father, and 212 children living with single fathers. 
of Table 1 shows that children go to bed later on weekend nights and that they go to bed later as they get older. The weekend-weekday difference in bedtimes is quite a bit smaller than the corresponding difference in wake-up times, and there is less variation in this difference by age. All of the differences in the lower panel are statistically significant at the 5-percent level.

Table 1 is suggestive, but to examine the effects of school and maternal employment on children's sleep patterns I now turn to the regression analysis.

\section{Regression Results}

Tables 3 and 4 show the regression results. The dependent variable in Table 3 is the amount of time children spent awake on the diary day (in minutes per day), and the dependent variables in Table 4 are the wake-up time and bedtime (both in minutes since 4:00 AM). All regressions were estimated using ATUS sample weights, and each equation includes controls for the child's age (3 categories) and sex, both parents' age and education, mother's race, family income (4 categories), presence of children age 13-17 in the household; and geographic indicators for region (4 regions), living in a city, and non-city MSA status (living in the suburbs). ${ }^{11}$

The main variables of interest are the mother's employment status, full-/part-time status, employment status interacted with child age category, whether the diary day was a workday for the child's mother, and whether the diary day was a school day. A mother is considered to be employed if she worked or had a job in the seven days prior to the ATUS interview, and she is considered to be part-time if she usually works fewer than 35 hours per week. I also included these employment variables interacted with an indicator for whether the child's mother is a single parent.

\footnotetext{
${ }^{11}$ I did not include father's race and child's race because they are highly correlated with mother's race.
} 
The workday variable is an indicator for whether the mother worked any time on the diary day. This measures the workday effect, net of any adjustments mothers might make to their work schedules. This net effect is what is relevant for policy purposes. Whether the effect of maternal employment on child awake time is a causal relationship or merely an association depends on the extent to which the maternal employment decision is endogenous. Clearly maternal employment is a choice. And if mothers of children who need more sleep are less likely to work, then these coefficients overestimate the causal effect of maternal employment. ${ }^{12}$ However, it seems likely that other factors drive maternal employment decisions.

The school day variable is an indicator for whether the diary day was a school day for the child and is defined as non-holiday weekdays during the school year. The school day effect can be interpreted as causal, because whether a day is a school day is clearly exogenous. However, the school day variable may overstate the effect of school on total sleep time if children sleep more on non-school days to make up for sleep lost during the school week. I investigate this possibility below.

Table 2 shows summary statistics for the key variables. The means are what one would expect, and indicate that the sample is representative. Note that 72 percent of mothers are employed, and 26 percent of employed mothers (19 percent of all mothers) work part time. And about half of the children in the sample have older siblings.

I report the regression results in Tables 3 and 4 separately for the school year and the summer. Because academic years vary considerably across school districts, I took the conservative approach of defining the school year as September $15^{\text {th }}$ through December $15^{\text {th }}$ and

\footnotetext{
${ }^{12}$ Stewart (2010) presents evidence that part-time employed mothers spend more time with their children and that they arrange their schedules to spend time with their children at times of day that enhance parent-child interactions. In contrast, full-time employed mothers appear to have very little flexibility regarding their schedule.
} 
January $15^{\text {th }}$ through May $15^{\text {th }}$. Summer is defined as June $15^{\text {th }}$ through August $31^{\text {st }} .{ }^{13}$

Observations that were not during either the school year or the summer were deleted. In Tables 3 and 4, I estimated all regressions on the full sample of school year and summer observations, and interacted the variables of interest (maternal employment) with a seasonal indicator to allow for differential effects in the summer and during the school year. ${ }^{14}$ Controls for parents’ demographic characteristics and geography were not interacted, so that the coefficients on these variables are constrained to be the same for the school year and the summer. Note that even though the summer and school year variables were estimated jointly, the reported coefficients are total effects (i.e., they are equal to the main effect plus the effect of the relevant seasonal interaction).

\section{Total Awake Time}

Equation (1) in Table 3 shows the results from the basic regression that includes maternal employment variables, but no day-specific variables. The coefficients on the child age variables are consistent with the result in Table 1 that older children spend more time awake and, not surprisingly, children with older siblings get less sleep (about 10 minutes per day). The control variables in the lower panel of Table 3 generally have no effect on total awake time. Only the indicator for the western region is statistically significant.

\footnotetext{
${ }^{13}$ Unfortunately, there is no way to know if children attended summer school or some other activity.

${ }^{14}$ To simplify both reporting and hypothesis testing I estimated two versions of each regression. The first regression includes the variables of interest (employment status, part-time status, etc, along with the interactions of these variables with the single mother indicator) plus each of these variables interacted with an indicator variable for Summer. I reported the main (non-interacted) effects in the School Year column. The second regression was estimated the same way except that the variables of interest were interacted with the School Year indicator instead of the Summer indicator. Analogously, the main (non-interacted) effects are reported in the Summer column. The equations are not fully interacted because the coefficients on the control variables are constrained to be the same for both seasons.
} 
Turning to the coefficients of interest, those on the maternal employment variables, it is important to keep in mind that this is an average effect over all seven days of the week, including days that the mother does not work. The coefficients indicate that maternal employment increases child awake time by about 10 minutes per day during the school year (not statistically significant) and by 31 minutes per day during the summer. The coefficients on the other maternal employment variables are not statistically significant, although the coefficients on the child-age $\times$ maternal employment interactions are large in the summer. The children of employed single mothers are awake an additional 48 minutes for a total of 79 minutes per day, compared to the children of non-employed single mothers.

Equation (2) in Table 3, which adds indicator variables for whether the mother worked on the diary day, illustrate how the maternal employment effect is distributed across work and nonwork days. As might be expected, the coefficient on the workday variable indicates that the reduction in sleep time occurs mainly on days that the mother works. During the school year, the coefficient on "Mother's Employment” decreases from 10 minutes per day (not statistically significant) to a statistically significant -20 minutes, while the coefficient on the "Mother's Workday” variable indicates that children sleep about 40 minutes less on days that their mothers work. Together these coefficients imply that children of employed mothers are awake 20 minutes less per day on non-work days (compared with children of non-employed mothers), but that they are awake 20 minutes longer (the net effect of the mother's workday and employment variables) on days that the mother works. Computing the total effect of these variables in the school column, we get $(7 \times-20+4.9 \times 40) / 7 \approx 8$, which is very close to the coefficient of 10 in the first column of Eequation (1). We see something similar in the summer column, although the coefficient on the maternal employment variable is no longer statistically significant. A similar 
calculation for the summer yields: $(7 \times 14+4.9 \times 26.5) / 7 \approx 33$, which is very close to the coefficient of 31 in the second column of Equation (1). ${ }^{15}$

Coefficients on the maternal employment $\times$ child age interactions are still statistically insignificant, although they are rather large in the summer equation. The coefficients on the single mother $\times$ employment variable interactions are large, but not statistically significant.

The last column, Equation (3), in Table 3 adds indicator variables for whether the diary day was a school day and a school day $\times$ workday interaction. ${ }^{16}$ The school day effect is largenearly an hour per day. And adding this variable virtually eliminates the effect of the maternal employment variables—even the workday indicators.

The large school day effect and the concomitant reduction in the coefficients on the maternal employment variables are likely due to the inflexibility of school schedules relative to mothers’ work schedules. It seems likely that mothers, especially those who work part time, have some flexibility with respect to their schedules. Or they select into jobs that have fixed, but compatible, work schedules that allow them to work when their children are in school. This interpretation is consistent with Stewart's (2010) findings that part-time employed mothers of school-age children tend to work at times when their children are at school, although he found no evidence that full-time employed mothers adjusted their schedules. Another possible explanation for the vanishing maternal employment effect is that married parents may adjust their schedules to form a "tag team.”

The day-specific variables explain a lot of the variation in total awake time. Adding the workday variable to the regression increased the $\mathrm{R}^{2}$ from 0.08 to 0.13 , and the inclusion of the

\footnotetext{
${ }^{15}$ Employed mothers in my sample work an average of 4.9 days per week.

${ }^{16}$ As with the previous regressions, this regression was estimated over both school year and summer observations. For obvious reasons, only the school year coefficients are shown.
} 
school day variable increased it further to 0.19 . That said, the estimated sleep loss of one hour per day on school days is not quite correct if one is interested in the amount of sleep children get on school nights, because school nights are not the same days of the week as school days.

\section{Wake-Up and Bed Times}

A better estimate of average total sleep time on school and non-school nights can be obtained by estimating separate regressions for wake-up and bed times (see Table 4). As in Table 3 the Summer and School Year coefficients on the variables of interest were estimated jointly. The wake-up equation includes indicators for whether the day was a school day, a workday, plus a school day $\times$ workday interaction. The bed time regression includes indicators for whether the night is a school night (i.e., whether the diary day was the day before a school day), a workday, and a school night $\times$ workday interaction. ${ }^{17}$ By combining the coefficient estimates from these two regressions, it is possible to calculate the effect of the covariates on average sleep times on school and non-school nights. This approach has the added advantage of allowing me to look at the timing of sleep and to determine whether children are losing sleep by going to bed later or getting up earlier, and thereby shed light on the extent to which sleep cycles may be disrupted. As with the time-awake regressions in Table 3, the summer and school-year coefficients were estimated jointly, but are presented in separate columns.

The Summer and School Year coefficients from the wake-up regression are in the first two columns of Table 4, and the coefficients from the bedtime regression are in the last two columns. These regressions include day variables and are analogous to the one in the last column of Table 3. The first thing to note is that the coefficients on the maternal employment variables are small

\footnotetext{
${ }^{17}$ It is not clear whether it is more appropriate to enter an indicator for workday or workday eve (the day before a workday). The workday variable is included because it is not possible to identify days before workdays.
} 
and not statistically significant. The coefficients on the school day $\times$ workday interactions are larger but still not statistically significant. The school day effects are large in both equationschildren go to bed about 38 minutes earlier on school nights and wake up about 72 minutes earlier on schooldays. The net effect is that children sleep about 34 minutes less on school nights than on non-school nights. ${ }^{18}$ This effect is large and statistically significant, and it implies that children have a cumulative sleep loss of close to 3 hours by the time they arrive at school on Friday morning.

Perhaps more important than the loss of sleep is the earlier wake-up time on school days. Research by Epstein et al. (1998) has shown that the disruption of the sleep cycle can reduce cognitive performance, independent of any sleep loss. The 72 minute earlier wake-up time suggests the potential for substantial disruption, but it is important to keep in mind that this is the difference in wake-up time relative to non-school days. In the next section, I consider the possibility that children make up for this lost sleep on weekends.

Only a few of the control variables are significant. Consistent with the findings in Table 1, the bed time regression indicates that older children (11-12 year-olds) go to bed about 30 minutes later than younger children. And children with older siblings go to bed about 12 minutes later than those with no older siblings. Children who live outside of urban and suburban settings wake up and go to bed 7-8 minutes earlier that those living in metropolitan areas. If these children have to travel farther to go to school, the earlier wake-up times could be due to the added time required to go to school.

\footnotetext{
${ }^{18}$ The implied 34 minute effect on total sleep time is not inconsistent with the 57 minute effect found in Table 3. The difference is that the school day variable in Table 3 does not account for the fact that children go to bed earlier on Sundays and stay up later on Fridays. When I reran the equation with the school day variable in place of the school night variable, the difference is 57 minutes (as in Table 3).
} 
Turning to the summer equations in the second and fourth columns of Table 4, we see that some of the coefficients on the maternal employment variables are large, especially the ones that are interacted with the single mother indicator. But the coefficient on the workday variable in the wake-up time equation is the only one that is statistically significant. The coefficient on the mother's workday variable indicates that children wake up 30 minutes earlier on days that their mothers work and that the longer awake time on workdays in Table 3 is due entirely to earlier wake-up times. Comparing non-school workdays during the school year and the summer, children wake up about 34 minutes earlier $(-29.5$ - 4.5) in the summer (the difference is statistically significant). The large summer-school year differential is likely due to the fact that non-school workdays during the school year are mostly weekend days, when fathers are more likely to be available to look after the kids.

\section{Do Children Make Up for Lost Sleep?}

If children make up for lost sleep on non-school nights, which one might expect, then the 34 minute effect of school on sleep time might overestimate the amount of sleep lost on school nights compared to the "optimal” amount sleep. This would be the case if children sleep less than the optimal amount on school nights and more than the optimal amount on non-school nights. Although there is no conclusive evidence on what the optimal amount of sleep is, it is still important to have a point of reference. Guidelines for 6-12 year-old children are that they should sleep 10-11 hours per night. ${ }^{19}$ I use this guideline as a starting point, and compare it to

\footnotetext{
${ }^{19}$ The National Institutes of Health (2011) recommends that school-age children and adolescents get at least 10 hours of sleep per night. The National Sleep Foundation recommends that children ages 5-12 get 10-11 hours of sleep per night (http://www.sleepfoundation.org/article/sleep-topics/children-and-sleep).
} 
the amount of sleep that children get when they not constrained by school or their mothers' work schedules (non-school days/nights that the mother does not work). ${ }^{20}$

For these comparisons, I used the regression results in Table 4 to generate predicted wakeup and bed times, and computed the implied average sleep times for eight sub-samples defined by school day/non-school day, school year/summer, mother employed/not employed, mother's workday/non-work day. These are shown in the upper panel of Table 5, with standard errors in parentheses. ${ }^{21}$ The lower panel shows selected comparisons, with asterisks indicating differences that are statistically significant. Because they are averages over the children of both single and married mothers, the estimated effects will, in a few cases, differ slightly from those reported in Table 4.

Four of the sub-samples consist of non-school days (nights) that are not workdays for the mother (lines 1, 4, 6, and 8). The first thing to note is that total sleep times for these lessconstrained subsamples generally fall within the recommended 10-11 hours per night. The only exceptions are for 11-12 year olds, who sleep slightly less than 10 hours during the school year (see lines 1 and 4). Within each age group, all of the differences in total sleep times across subsamples are small and none is statistically significant. These differences can be seen in the first three rows of the lower panel of Table 5. The similarity of the estimates for these four subsamples leads me to conclude that, although children do sleep more on non-school nights, they

\footnotetext{
${ }^{20}$ It is worth pointing out that using summer sleep patterns as a comparison group is potentially problematic. Children may be more physically active in the summer and may tend to sleep more. Working in the other direction, the daylight hours are longer in the summer, which may lead to children to sleep less.

${ }^{21}$ For each sub-sample in Table 5, I computed the predicted values using the coefficients on the relevant indicator variables for mother's employment status and whether the diary day was a school day or a workday. To obtain an average over entire sample, I weighted the coefficients on the single-mother $\times$ employment interactions by multiplying these coefficients by the fraction of single mothers in the sample. The effect of the remaining control variables are evaluated at their sample means. I computed standard errors by first generating the standard error of the predicted value for each observation. I then averaged these standard errors over over the relevant subgroup (for example, the children of full-time employed mothers on school days (nights)).
} 
do not make up sleep that is lost during the school week. So for my comparisons, I use the nonworkday, non-school day (night) sub-samples as the point of reference.

The next set of comparisons is the school day/non-school day difference for the children of full-time employed mothers on non-work days (a comparison of lines (2) and (1)). As we saw in Table 4, children wake up earlier on schooldays and go to bed earlier on school nights. The net effect of these differences is that children sleep about one-half of an hour less on school nights compared to non-school nights. As in Table 4, the differences in wake-up and bed times are statistically significant at the 1-percent level. The differences in total sleep time are statistically significant at the 5-percent level.

On school days when the child's mother works (line (3)), children wake up a little earlier. The comparison of lines (2) and (3) shows that, on school days that are also workdays, children wake up about 15 minutes earlier than on non-work school days, but none of the differences are statistically significant. Even though these differences are not statistically significant, they suggest that school is not the binding constraint on days that the mother works. Rather, the results suggest that later school start times would not result in children of employed mothers waking up any later on days that their mothers work.

However, if we look at when children wake up on days that their mothers work in the summer, we see that they wake up much later compared to workdays that are also school days. This suggests that even the children of employed mothers would benefit from later school start times. There are a couple of possible explanations for these apparently contradictory results. The first is that mothers may alter their work schedules for the summer months, perhaps to accommodate the later start times (at least compared to school start times) of summer camps and other activities. The second is that older siblings, who are also out of school, may look after 
younger siblings, allowing them to sleep later. One piece of evidence in support of this is that wake-up times in line 3 (workdays in the summer) increase with age. As I noted in footnote 9, the fraction of children with older siblings increases with age.

\section{Sleep Cycle Effects}

Apart from the effects on total sleep time, school and maternal employment can potentially disrupt natural sleep cycles by altering bed and wake-up times. As with total sleep times, there is little difference in wake-up and bed times across the four non-school day (night), non-workday subsamples. Average bed times are fairly similar across these subsamples, ranging from about 9:30 PM to about 9:45 PM for 6-8 year-olds, between 9:55 PM and 10:15 PM for 9-10 year-olds, and between 10:15 PM and 10:25 PM for 11-12 year-olds. Average wake-up times are about the same for these subsamples, ranging between 8:00 AM and 8:20 AM for 6-8 year-olds, between 8:10 AM and 8:35 AM for 9-10 year-olds, and between 8:10 AM and 8:45 AM for 11-12 yearold children. Thus, it appears that children naturally wake up between 8:00 AM and 8:45 AM when they are not constrained by school or their mothers’ work schedules.

On school days, the average wake-up time is right around 7:00 AM, with very little variation across age groups or by employment status of the mother. The earlier wake-up times on school days likely disrupt children's sleep cycles, which could lead to diminished academic performance. The study by Epstein et al. (1998), which found that earlier school start times led to sleepiness and a reduced ability to concentrate, also found that this effect is independent of the amount of sleep children get. Thus, earlier school start times potentially affect academic performance through disrupted sleep cycles as well as loss of sleep. 


\section{Discussion and Conclusions}

This study is the first attempt to systematically look the effects of school and maternal employment on the sleep patterns of elementary school age children. Most research on the effect of school on sleep has focused on high school students. And the few studies that have looked at the effect of maternal employment on sleep did not did not distinguish between the summer and the school year, and therefore could not account for any interaction between school and maternal employment.

I find that children sleep less during the school year than over the summer. More to the point, children sleep less on school nights than on non-school nights. Children go to bed about 38 minutes earlier on school nights, compared to non-school nights. But they wake-up 72 minutes earlier on school days, for a net sleep loss of about 34 minutes per night. By the end of the week, the cumulative sleep loss is close to three hours. Research by Banks and Dinges (2007) has shown that the negative effects of consecutive nights of sleep deficits on cognitive performance are cumulative, which implies that this accumulated sleep debt matters. Put another way, these children spend 20 percent of their time in school (Fridays) with an accumulated sleep debt of close to three hours.

To fully make up for sleep lost during the school week, children would have to sleep close to 12 hours on each of the weekend nights. Children do sleep longer on non-school nights, but there is no evidence that they are making up for sleep lost during the week. The amount of sleep that they get on non-school nights during the school year falls right in the middle of the recommended 10-11 hours of sleep per night. Moreover, the sleep patterns (wake-up and bed times) of children on non-school nights during the school year are very similar to summer sleep patterns, which is a reasonable approximation of the amount of sleep these children "should” get. 
Children also sleep less when their mothers are employed. In the summertime, kids wake up about 30 minutes earlier on days that their mothers work, yet their bed times are about the same on work and non-workdays. As is the case over the school year, children do not seem to be making up for lost sleep.

Assessing the effect of maternal employment during the school year is a little more complicated. The coefficient on the workday variable on child wake-up times is small (and slightly negative) and not statistically significant. This finding suggests that later school start times would not have much effect on the children of full-time employed mothers, because they would still have to wake up earlier to accommodate their mothers' work schedules. Unless their mothers can rearrange their work schedules to accommodate later start times, these children might simply spend more time in before-school care and not get any more sleep. However, if we look at when children wake up on days that their mothers work in the summer we see that they wake up much later than on school days, which suggests that the children of employed mothers would sleep longer with later school start times. There are two possible explanations for this apparent contradiction; (1) mothers may rearrange their work schedules in the summer, or (2) mothers may rely on older children in the family to look after the younger children, which would allow the younger children to sleep longer while the mothers maintain their regular work schedule. There is some evidence that the latter is the case, but it bears further investigation.

In addition to the loss of sleep, the earlier wake-up times on school days appear to disrupt children's natural sleep cycles. Compared with the four subsamples of days when sleep is not constrained by school or their mothers' work schedules, these children wake up about an hour and 15 minutes earlier than their natural sleep cycles would seem to dictate. Some of this is made up by earlier bed times on school nights, but earlier bed times only (partially) compensate 
for the loss of sleep. The study by Epstein et al. (1998) found that the disruption of the sleep cycle leads to sleepiness and a reduced ability to concentrate, independent of the amount of sleep children get. This, in turn, suggests a diminution of academic performance as well.

One should also keep in mind that these are average effects across person days, and that they say nothing about the distribution of these effects across children over all days. It would be interesting to know whether these effects are evenly distributed across children or are concentrated among a relatively small group of school-age children. Unfortunately, there is no way to look at the distribution of children's average sleep times using time-diary data, because sleep patterns on the diary day do not necessarily reflect the child's long-run sleep patterns. An analysis of this type would be informative, but would require different data. ${ }^{22}$

\footnotetext{
${ }^{22}$ See Frazis and Stewart (2011) for an analysis of what can and cannot be estimated using time-diary data.
} 


\section{References}

Anderson, Patricia M., Kristen F. Butcher, and Phillip B. Levine (2003) Maternal employment and overweight children.” Journal of Health Economics 22, pp. 477-504.

Banks, Siobhan and David F. Dinges (2007) "Behavioral and Physiological Consequences of Sleep Restriction.” Journal of Clinical Sleep Medicine 3(5), pp. 519-528.

Baum II, Charles (2003) "Does Early Maternal Employment Harm Child Development? An Analysis of the Potential Benefits of Leave Taking.” Journal of Labor Economics 21(2), pp. 409-448.

Carskadon, Mary, Cecilia Viera, and Christine Acebo (1993) “Association between Puberty and Delayed Sleep Preference.” Sleep 16(3), pp. 258-262.

Carrell, Scott E., Teny Maghakian, and James E. West (2011) “A’s from Zzzz’s? The Causal Effect of School Start Time on the Academic Achievement of Adolescents." forthcoming in American Economic Review: Economic Policy.

Cawley, John and Feng Liu (2007a) "Mechanisms for the Association between Maternal Employment and Child Cognitive Development.” NBER Working Paper 13609.

Cawley, John and Feng Liu (2007b) "Maternal Employment and Child Obesity: A Search for Mechanisms Time Use Data.” NBER Working Paper 13600.

Crowley, Stephanie, Christine Acebo, and Mary Carskadon (2007) "Sleep, Circadian Rhythms, and Delayed Phase in Adolescents.” Sleep Medicine 8, pp. 602-612.

Epstein, R., N. Chillag, and P. Lavie (1998) "Starting Times of School: Effects on Daytime Functioning of Fifth-grade Children in Israel.” Sleep 21(3), pp. 250-256.

Fallone, Gahan, Christine Acebo, Ronald Seifer, and Mary Carskadon (2005) "Experimental Restriction of Sleep Opportunity in Children: Effects on Teacher Ratings.” Sleep 28(12), pp. 1561-1567.

Fertig, Angela, Gerhard Glomm, and Rusty Tchernis (2009) “The connection between maternal employment and childhood obesity: inspecting the mechanisms.” Review of Economics of the Household 7, pp227-255.

Frazis, Harley and Jay Stewart (2007) "Where Does the Time Go? Concepts and Measurement in the American Time Use Survey.” In Hard to Measure Goods and Services: Essays in Memory of Zvi Griliches, Ernst Berndt and Charles Hulten, eds., NBER Studies in Income and Wealth, University of Chicago Press, 2007.)

Frazis, Harley and Jay Stewart (2011) "How to Think About Time-Use Data: What Inferences Can We Make About Long- and Short-Run Time Use from Time Diaries?” Annales d'Economie et Statistique (Annals of Economics and Statistics) 105/106 (January/June 2012), pp. 231-246.

Gangwisch, James E., Dolores Malaspina, Bernadette Boden-Albala, and Steven B. Heymsfield (2005) "Inadequate Sleep as a Risk Factor for Obesity: Analyses of NHANES I." Sleep 28(10), pp. 1289-1296. 
Gordon, Rachel A., Robert Kaestner, and Sanders Korenman (2007) "The Effects of Maternal Employment on Child Injuries and Infectious Disease.” Demography 44(2), pp. 307-333.

Hale, Lauren, Lawrence M. Berger, Monique K. LeBourgeois, and Jeanne Brooks-Gunn (2009) "Social and Demographic Predictors of Preschoolers' Bedtime Routines.” Journal of Developmental \& Behavioral Pediatrics 30, pp. 394-402.

Hamermesh, Daniel S., Harley Frazis, and Jay Stewart (2005) "Data Watch: The American Time Use Survey.” Journal of Economic Perspectives 19(1), Winter 2005, pp. 221-232.

Hofferth, Sandra and John F. Sandberg (2001) "How American Children Spend Their Time.” Journal of Marriage and Family 63(2), May 2001, pp. 295-308.

James-Burdumy, Susanne (2005) "The effect of Maternal Labor Force Participation on Child Development.” Journal of Labor Economics 23(1), pp. 177-211.

Morrill, Melinda Sandler (2010) "The Effects of Maternal Employment on the Health of SchoolAge Children.” Unpublished manuscript, North Carolina State University.

Ruhm, Christopher (2004) “Parental Employment and Child Cognitive Development” Journal of Human Resources, 39(1), pp. 155-92.

Stewart, Jay (2010) “The Timing of Maternal Work and Time with Children,” Industrial and Labor Relations Review 64(1), October 2010, pp. 181-200. 
Table 1: Total Time Spent Awake by Age of Child and Day of Week

(hours per day)

\begin{tabular}{|c|c|c|c|}
\hline \multicolumn{4}{|c|}{ Time Spent Awake } \\
\hline & & Weekends 8 & \\
\hline & Weekdays & Holidays & Total \\
\hline \multicolumn{4}{|c|}{ Age of Child } \\
\hline $6-8$ & 14.13 & 13.34 & 13.92 \\
\hline $9-10$ & 14.31 & 13.54 & 14.09 \\
\hline $11-12$ & 14.78 & 13.59 & 14.46 \\
\hline \multicolumn{4}{|c|}{ Wake-up Time } \\
\hline & & Weekends $\&$ & \\
\hline & Weekdays & Holidays & Total \\
\hline \multicolumn{4}{|c|}{ Age of Child } \\
\hline $6-8$ & 7.08 & 8.23 & 7.39 \\
\hline $9-10$ & 7.16 & 8.32 & 7.48 \\
\hline $11-12$ & 7.16 & 8.49 & 7.52 \\
\hline \multicolumn{4}{|c|}{ Bedtime } \\
\hline & & Weekends \& & \\
\hline & Weekdays & Holidays & Total \\
\hline \multicolumn{4}{|c|}{ Age of Child } \\
\hline $6-8$ & 21.21 & 21.57 & 21.31 \\
\hline $9-10$ & 21.47 & 21.86 & 21.58 \\
\hline $11-12$ & 21.94 & 22.09 & 21.98 \\
\hline
\end{tabular}




\begin{tabular}{|c|c|c|}
\hline & Mean & $\begin{array}{l}\text { Standard } \\
\text { Deviation }\end{array}$ \\
\hline Mother Employed & 0.717 & $(0.450)$ \\
\hline Mother Works PT & 0.189 & $(0.392)$ \\
\hline Mother Employed x Age 6-8 & 0.232 & $(0.422)$ \\
\hline Mother Employed x Age 9-10 & 0.206 & $(0.404)$ \\
\hline Mother Employed x Age 11-12 & 0.280 & (0.449) \\
\hline Single Mother & 0.275 & $(0.447)$ \\
\hline S Mother Employed & 0.203 & $(0.402)$ \\
\hline S Mother Works PT & 0.042 & $(0.201)$ \\
\hline \multicolumn{3}{|l|}{ Age of Child } \\
\hline 6-8 & 0.321 & $(0.467)$ \\
\hline $9-10$ & 0.293 & $(0.455)$ \\
\hline $11-12$ & 0.386 & $(0.487)$ \\
\hline Gender of Child (Female) & 0.498 & $(0.500)$ \\
\hline Presence of Children 13-17 in Household & 0.493 & $(0.500)$ \\
\hline Mother's Age & 40.256 & (6.795) \\
\hline Mother's Race (Nonwhite) & 0.196 & $(0.397)$ \\
\hline \multicolumn{3}{|l|}{ Mother's Education } \\
\hline No HS Diploma & 0.100 & $(0.300)$ \\
\hline HS Diploma & 0.307 & $(0.461)$ \\
\hline Some College & 0.290 & $(0.454)$ \\
\hline College Graduate & 0.303 & $(0.459)$ \\
\hline Father's Age ${ }^{\dagger}$ & 43.560 & (7.034) \\
\hline Fathers Race (Nonwhite)† & 0.169 & $(0.375)$ \\
\hline \multicolumn{3}{|l|}{ Father's Educationt } \\
\hline No HS Diploma & 0.112 & $(0.315)$ \\
\hline HS Diploma & 0.295 & $(0.456)$ \\
\hline Some College & 0.244 & $(0.430)$ \\
\hline College Graduate & 0.346 & $(0.476)$ \\
\hline \multicolumn{3}{|l|}{ Family Income } \\
\hline$<\$ 25 K$ & 0.134 & $(0.341)$ \\
\hline$\$ 25 K-\$ 49 K$ & 0.208 & $(0.406)$ \\
\hline$\$ 50 K-\$ 74 K$ & 0.181 & $(0.385)$ \\
\hline$\$ 75 K+$ & 0.149 & $(0.356)$ \\
\hline \multicolumn{3}{|l|}{ Region } \\
\hline South & 0.365 & $(0.482)$ \\
\hline Northeast & 0.201 & $(0.400)$ \\
\hline Midwest & 0.228 & (0.419) \\
\hline West & 0.207 & $(0.405)$ \\
\hline City & 0.218 & $(0.413)$ \\
\hline Non-city MSA & 0.471 & $(0.499)$ \\
\hline School Year & 0.755 & $(0.430)$ \\
\hline
\end{tabular}

† The means for father's variables were computed using the subsample of children with married parents. 
Table 3: Determinants of Child Awake Time

\begin{tabular}{|c|c|c|c|c|c|}
\hline & \multicolumn{2}{|c|}{ (1) } & \multicolumn{2}{|c|}{ (2) } & \multirow{2}{*}{$\begin{array}{c}\text { (3) } \\
\text { School Year }\end{array}$} \\
\hline & School Year & Summer & School Year & Summer & \\
\hline Mother Employed & $\begin{array}{l}10.4 \\
(7.5)\end{array}$ & $\begin{array}{c}31.1 \\
(13.9)\end{array}$ & $\begin{array}{l}-20.4^{*} \\
(8.2)\end{array}$ & $\begin{array}{r}14.0 \\
(15.7)\end{array}$ & $\begin{array}{r}-1.0 \\
(8.1)\end{array}$ \\
\hline Mother Works PT & $\begin{array}{r}-3.4 \\
(5.1)\end{array}$ & $\begin{array}{r}5.8 \\
(13.8)\end{array}$ & $\begin{array}{r}2.3 \\
(5.0)\end{array}$ & $\begin{array}{r}6.7 \\
(13.4)\end{array}$ & $\begin{array}{r}-1.3 \\
(4.8)\end{array}$ \\
\hline $\begin{array}{c}\text { Mother Employed } \\
\text { x Age 9-10 }\end{array}$ & $\begin{array}{r}-13.4 \\
(9.2)\end{array}$ & $\begin{array}{r}-23.4 \\
(20.5)\end{array}$ & $\begin{array}{r}-11.6 \\
(9.1)\end{array}$ & $\begin{array}{r}-23.2 \\
(20.1)\end{array}$ & $\begin{array}{r}-9.6 \\
(8.9)\end{array}$ \\
\hline $\begin{array}{c}\text { Mother Employed } \\
\text { x Age 11-12 }\end{array}$ & $\begin{array}{r}-6.2 \\
(9.9)\end{array}$ & $\begin{array}{r}-36.3 \\
(19.9)\end{array}$ & $\begin{array}{l}-3.7 \\
(9.8)\end{array}$ & $\begin{array}{r}-35.8 \\
(19.8)\end{array}$ & $\begin{array}{l}-1.7 \\
(9.1)\end{array}$ \\
\hline Workday (Mother) & & & $\begin{array}{l}40.0^{* *} \\
(4.8)\end{array}$ & $\begin{array}{l}26.5 * \\
(10.9)\end{array}$ & $\begin{array}{r}5.3 \\
(8.2)\end{array}$ \\
\hline School day & & & & & $\begin{array}{l}57.5^{* *} \\
(5.4)\end{array}$ \\
\hline School day $\times$ Workday & & & & & $\begin{array}{r}3.5 \\
(9.4)\end{array}$ \\
\hline Single Mother & $\begin{array}{r}8.0 \\
(16.8)\end{array}$ & $\begin{array}{l}-10.7 \\
(20.4)\end{array}$ & $\begin{array}{r}-0.7 \\
(16.7)\end{array}$ & $\begin{array}{r}-17.9 \\
(20.4)\end{array}$ & $\begin{array}{r}-0.1 \\
(16.9)\end{array}$ \\
\hline S Mother Employed & $\begin{array}{r}12.2 \\
(10.4)\end{array}$ & $\begin{array}{c}47.7 * \\
(21.6)\end{array}$ & $\begin{array}{r}6.4 \\
(11.8)\end{array}$ & $\begin{array}{r}22.5 \\
(25.5)\end{array}$ & $\begin{array}{r}4.3 \\
(11.5)\end{array}$ \\
\hline S Mother Works PT & $\begin{array}{r}-15.1 \\
(9.9)\end{array}$ & $\begin{array}{l}-28.6 \\
(30.6)\end{array}$ & $\begin{array}{r}-17.4 \\
(9.8)\end{array}$ & $\begin{array}{r}-29.2 \\
(29.2)\end{array}$ & $\begin{array}{r}-16.5 \\
(9.4)\end{array}$ \\
\hline $\begin{array}{c}\text { S Mother Employed } \\
\text { x Age 9-10 }\end{array}$ & $\begin{array}{r}1.6 \\
(9.7)\end{array}$ & $\begin{array}{r}-29.5 \\
(28.4)\end{array}$ & $\begin{array}{r}2.3 \\
(9.4)\end{array}$ & $\begin{array}{r}-19.2 \\
(28.0)\end{array}$ & $\begin{array}{r}3.1 \\
(9.1)\end{array}$ \\
\hline $\begin{array}{l}\text { S Mother Employed } \\
\text { x Age 11-12 }\end{array}$ & $\begin{array}{l}-3.2 \\
(9.6)\end{array}$ & $\begin{array}{r}5.2 \\
(35.3)\end{array}$ & $\begin{array}{l}-6.0 \\
(9.2)\end{array}$ & $\begin{array}{r}11.5 \\
(34.6)\end{array}$ & $\begin{array}{r}-3.1 \\
(8.8)\end{array}$ \\
\hline Workday (S Mother) & & & $\begin{array}{l}14.5 \\
(8.2)\end{array}$ & $\begin{array}{r}30.7 \\
(23.3)\end{array}$ & $\begin{array}{r}4.4 \\
(14.3)\end{array}$ \\
\hline $\begin{array}{l}\text { School day } x \\
\quad x \text { Single Mother }\end{array}$ & & & & & $\begin{array}{r}-5.3 \\
(10.0)\end{array}$ \\
\hline $\begin{array}{c}\text { School day } \mathrm{x} \text { Workday } \\
\mathrm{x} \text { Single Mother }\end{array}$ & & & & & $\begin{array}{r}13.3 \\
(16.7)\end{array}$ \\
\hline Child Age 9-10 & $\begin{array}{l}20.4^{* *} \\
(7.3)\end{array}$ & $\begin{array}{r}27.3 \\
(14.1)\end{array}$ & $\begin{array}{l}20.2^{* *} \\
(7.2)\end{array}$ & $\begin{array}{r}26.0 \\
(13.9)\end{array}$ & $\begin{array}{l}18.1 * \\
(7.1)\end{array}$ \\
\hline Child Age 11-12 & $\begin{array}{l}40.7 * * \\
(8.1)\end{array}$ & $\begin{array}{r}38.3 * \\
(14.9)\end{array}$ & $\begin{array}{l}39.7 * * \\
(8.1)\end{array}$ & $\begin{array}{c}37.9 * \\
(15.0)\end{array}$ & $\begin{array}{l}38.1^{* *} \\
(7.4)\end{array}$ \\
\hline Child Gender (Female) & $\begin{array}{r}-4.5 \\
(3.3)\end{array}$ & $\begin{array}{r}-4.8 \\
(7.9)\end{array}$ & $\begin{array}{r}-5.7 \\
(3.2)\end{array}$ & $\begin{array}{l}-3.6 \\
(7.7)\end{array}$ & $\begin{array}{r}-4.7 \\
(3.0)\end{array}$ \\
\hline $\begin{array}{l}\text { Presence of Children } \\
13-17 \text { in Household }\end{array}$ & $\begin{array}{l}9.3^{* *} \\
(3.4)\end{array}$ & $\begin{array}{r}-7.9 \\
(9.1)\end{array}$ & $\begin{array}{l}9.2^{* *} \\
(3.3)\end{array}$ & $\begin{array}{r}-6.6 \\
(8.9)\end{array}$ & $\begin{array}{l}9.6^{* *} \\
(3.1)\end{array}$ \\
\hline
\end{tabular}


Table 3: Determinants of Child Awake Time (continued)

\begin{tabular}{|c|c|c|c|}
\hline & $\begin{array}{l}\text { Summer and } \\
\text { School Year } \\
\end{array}$ & $\begin{array}{l}\text { Summer and } \\
\text { School Year } \\
\end{array}$ & $\begin{array}{l}\text { Summer and } \\
\text { School Year }\end{array}$ \\
\hline Mother's Age & $\begin{array}{r}0.0 \\
(0.3)\end{array}$ & $\begin{array}{r}0.1 \\
(0.3)\end{array}$ & $\begin{array}{r}0.1 \\
(0.3)\end{array}$ \\
\hline Mother's Race (Nonwhite) & $\begin{array}{r}5.4 \\
(5.4)\end{array}$ & $\begin{array}{r}5.4 \\
(5.2)\end{array}$ & $\begin{array}{r}7.1 \\
(5.1)\end{array}$ \\
\hline M - No HS Diploma & $\begin{array}{l}-6.5 \\
(6.9)\end{array}$ & $\begin{array}{r}-4.7 \\
(6.7)\end{array}$ & $\begin{array}{l}-1.7 \\
(6.5)\end{array}$ \\
\hline M - Some College & $\begin{array}{l}-2.3 \\
(4.5)\end{array}$ & $\begin{array}{l}-1.2 \\
(4.3)\end{array}$ & $\begin{array}{l}-1.4 \\
(4.2)\end{array}$ \\
\hline M - College Graduate & $\begin{array}{r}1.2 \\
(4.8)\end{array}$ & $\begin{array}{l}-0.3 \\
(4.6)\end{array}$ & $\begin{array}{r}1.7 \\
(4.5)\end{array}$ \\
\hline Father's Age & $\begin{array}{r}0.2 \\
(0.3)\end{array}$ & $\begin{array}{r}0.1 \\
(0.3)\end{array}$ & $\begin{array}{r}0.0 \\
(0.3)\end{array}$ \\
\hline Fathers Race (Nonwhite) & $\begin{array}{l}-3.7 \\
(6.3)\end{array}$ & $\begin{array}{l}-2.9 \\
(6.1)\end{array}$ & $\begin{array}{l}-4.3 \\
(6.0)\end{array}$ \\
\hline F - No HS Diploma & $\begin{array}{r}2.9 \\
(7.2)\end{array}$ & $\begin{array}{r}2.9 \\
(7.0)\end{array}$ & $\begin{array}{r}2.6 \\
(6.7)\end{array}$ \\
\hline F - Some College & $\begin{array}{r}3.5 \\
(5.4)\end{array}$ & $\begin{array}{r}3.1 \\
(5.3)\end{array}$ & $\begin{array}{r}3.8 \\
(5.1)\end{array}$ \\
\hline F - College Graduate & $\begin{array}{r}6.2 \\
(5.6)\end{array}$ & $\begin{array}{r}6.0 \\
(5.4)\end{array}$ & $\begin{array}{r}6.7 \\
(5.3)\end{array}$ \\
\hline Family Income \$25K-\$49K & $\begin{array}{r}4.3 \\
(5.3)\end{array}$ & $\begin{array}{r}3.2 \\
(5.2)\end{array}$ & $\begin{array}{r}1.7 \\
(5.0)\end{array}$ \\
\hline Family Income \$50K-\$74K & $\begin{array}{r}5.9 \\
(5.0)\end{array}$ & $\begin{array}{r}5.4 \\
(4.9)\end{array}$ & $\begin{array}{r}5.0 \\
(4.7)\end{array}$ \\
\hline Family Income \$75K+ & $\begin{array}{r}8.8 \\
(5.0)\end{array}$ & $\begin{array}{r}8.0 \\
(4.9)\end{array}$ & $\begin{array}{r}6.5 \\
(4.8)\end{array}$ \\
\hline South & $\begin{array}{r}2.4 \\
(4.3)\end{array}$ & $\begin{array}{r}1.4 \\
(4.2)\end{array}$ & $\begin{array}{r}-0.4 \\
(4.1)\end{array}$ \\
\hline Northeast & $\begin{array}{l}-1.9 \\
(4.6)\end{array}$ & $\begin{array}{r}-2.9 \\
(4.5)\end{array}$ & $\begin{array}{l}-3.4 \\
(4.4)\end{array}$ \\
\hline West & $\begin{array}{l}-10.3 * \\
(4.7)\end{array}$ & $\begin{array}{l}-11.8 * \\
(4.6)\end{array}$ & $\begin{array}{l}-11.2 * \\
(4.5)\end{array}$ \\
\hline City & $\begin{array}{l}-2.4 \\
(4.4)\end{array}$ & $\begin{array}{l}-1.6 \\
(4.3)\end{array}$ & $\begin{array}{l}-2.6 \\
(4.2)\end{array}$ \\
\hline Non-city MSA & $\begin{array}{r}0.9 \\
(3.7)\end{array}$ & $\begin{array}{r}-0.8 \\
(3.6)\end{array}$ & $\begin{array}{l}-2.1 \\
(3.5)\end{array}$ \\
\hline School Year & $\begin{array}{r}21.9 \\
(13.0)\end{array}$ & $\begin{array}{r}24.0 \\
(13.0)\end{array}$ & $\begin{array}{r}-15.4 \\
(13.3)\end{array}$ \\
\hline Constant & $\begin{array}{l}791.6^{* *} \\
(17.9)\end{array}$ & $\begin{array}{l}796.8^{* *} \\
(17.8)\end{array}$ & $\begin{array}{l}798.4^{* *} \\
(17.3)\end{array}$ \\
\hline R-squared & 0.082 & 0.129 & 0.190 \\
\hline Observations & 3,226 & 3,226 & 3,226 \\
\hline
\end{tabular}

The Summer and School Year coefficients for the main variables of interest were estimated jointly for each equation (there were 2,436 School Year observations and 790 Summer observations), but the control variables were constrained to have common effects. Summer coefficients are not reported for equation (3). Details about the estimation are in footnote 15. Standard errors are in parentheses.

* Significant at the $5 \%$ level. ${ }^{* *}$ Significant at the $1 \%$ level. 
Table 4: Determinants of Child Wake-Up and Bed Times

\begin{tabular}{|c|c|c|c|c|}
\hline & \multicolumn{2}{|c|}{ Wake-Up Time } & \multicolumn{2}{|c|}{ Bed Time } \\
\hline & $\begin{array}{c}\text { During School } \\
\text { Year }\end{array}$ & Summer & $\begin{array}{c}\text { During School } \\
\text { Year }\end{array}$ & Summer \\
\hline Mother Employed & $\begin{array}{r}-2.6 \\
(6.7)\end{array}$ & $\begin{array}{r}-12.5 \\
(14.8)\end{array}$ & $\begin{array}{r}-2.0 \\
(6.7)\end{array}$ & $\begin{array}{r}1.6 \\
(9.8)\end{array}$ \\
\hline Mother Works PT & $\begin{array}{r}1.4 \\
(3.7)\end{array}$ & $\begin{array}{r}-0.8 \\
(11.4)\end{array}$ & $\begin{array}{r}1.0 \\
(4.0)\end{array}$ & $\begin{array}{r}6.2 \\
(8.0)\end{array}$ \\
\hline $\begin{array}{l}\text { Mother Employed } \\
\text { x Age 9-10 }\end{array}$ & $\begin{array}{r}7.8 \\
(7.6)\end{array}$ & $\begin{array}{r}2.2 \\
(19.7)\end{array}$ & $\begin{array}{r}-3.4 \\
(7.4)\end{array}$ & $\begin{array}{r}-20.9 \\
(13.6)\end{array}$ \\
\hline $\begin{array}{c}\text { Mother Employed } \\
\text { x Age 11-12 }\end{array}$ & $\begin{array}{r}2.5 \\
(7.9)\end{array}$ & $\begin{array}{r}33.3 \\
(18.3)\end{array}$ & $\begin{array}{r}1.6 \\
(7.6)\end{array}$ & $\begin{array}{r}-2.0 \\
(14.3)\end{array}$ \\
\hline Workday (Mother) & $\begin{array}{r}4.5 \\
(8.1)\end{array}$ & $\begin{array}{l}-29.5 * * \\
(9.5)\end{array}$ & $\begin{array}{r}6.8 \\
(6.9)\end{array}$ & $\begin{array}{l}-3.0 \\
(7.4)\end{array}$ \\
\hline School day (night) & $\begin{array}{l}-71.8^{* *} \\
(4.7)\end{array}$ & & $\begin{array}{l}-38.0 * * \\
(4.6)\end{array}$ & \\
\hline School day (night) x Workday & $\begin{array}{r}-15.8 \\
(9.2)\end{array}$ & & $\begin{array}{r}-11.6 \\
(7.4)\end{array}$ & \\
\hline Single Mother & $\begin{array}{r}16.9 \\
(16.1)\end{array}$ & $\begin{array}{r}20.4 \\
(20.2)\end{array}$ & $\begin{array}{r}22.7 \\
(14.5)\end{array}$ & $\begin{array}{r}5.4 \\
(14.3)\end{array}$ \\
\hline S Mother Employed & $\begin{array}{r}-5.8 \\
(9.7)\end{array}$ & $\begin{array}{r}-17.3 \\
(22.8)\end{array}$ & $\begin{array}{r}-2.1 \\
(9.5)\end{array}$ & $\begin{array}{r}5.6 \\
(15.6)\end{array}$ \\
\hline S Mother Works PT & $\begin{array}{r}1.0 \\
(7.1)\end{array}$ & $\begin{array}{r}28.6 \\
(23.8)\end{array}$ & $\begin{array}{r}-15.8 \\
(8.2)\end{array}$ & $\begin{array}{r}-2.2 \\
(18.2)\end{array}$ \\
\hline $\begin{array}{l}\text { S Mother Employed } \\
\text { x Age } 9-10\end{array}$ & $\begin{array}{r}-0.6 \\
(7.2)\end{array}$ & $\begin{array}{r}20.6 \\
(24.1)\end{array}$ & $\begin{array}{r}2.5 \\
(7.1)\end{array}$ & $\begin{array}{r}1.6 \\
(16.6)\end{array}$ \\
\hline $\begin{array}{c}\text { S Mother Employed } \\
\text { x Age 11-12 }\end{array}$ & $\begin{array}{r}6.5 \\
(6.8)\end{array}$ & $\begin{array}{r}-7.4 \\
(22.4)\end{array}$ & $\begin{array}{r}3.8 \\
(7.6)\end{array}$ & $\begin{array}{r}4.4 \\
(22.4)\end{array}$ \\
\hline Workday (S Mother) & $\begin{array}{r}-4.4 \\
(12.7)\end{array}$ & $\begin{array}{r}-21.1 \\
(17.4)\end{array}$ & $\begin{array}{r}-13.6 \\
(12.3)\end{array}$ & $\begin{array}{r}9.8 \\
(14.9)\end{array}$ \\
\hline $\begin{array}{l}\text { Schoolday (night) } \\
\text { x Single Mother }\end{array}$ & $\begin{array}{r}-4.7 \\
(9.0)\end{array}$ & & $\begin{array}{l}-6.9 \\
(9.5)\end{array}$ & \\
\hline $\begin{array}{l}\text { Schoolday (night) x Workday } \\
\text { x Single Mother }\end{array}$ & $\begin{array}{r}-8.9 \\
(14.9)\end{array}$ & & $\begin{array}{r}16.0 \\
(13.6)\end{array}$ & \\
\hline Child Age 9-10 & $\begin{array}{l}-5.8 \\
(6.4)\end{array}$ & $\begin{array}{r}11.1 \\
(14.7)\end{array}$ & $\begin{array}{l}11.3 \\
(6.0)\end{array}$ & $\begin{array}{l}37.3^{* *} \\
(10.3)\end{array}$ \\
\hline Child Age 11-12 & $\begin{array}{l}-6.6 \\
(6.5)\end{array}$ & $\begin{array}{r}8.5 \\
(13.8)\end{array}$ & $\begin{array}{l}29.6 * * \\
(6.3)\end{array}$ & $\begin{array}{l}46.0 * * \\
(11.6)\end{array}$ \\
\hline Child Gender (Female) & $\begin{array}{r}3.4 \\
(2.5)\end{array}$ & $\begin{array}{r}-8.7 \\
(7.0)\end{array}$ & $\begin{array}{r}0.4 \\
(2.4)\end{array}$ & $\begin{array}{l}-12.1 * \\
(5.4)\end{array}$ \\
\hline $\begin{array}{l}\text { Presence of Children } \\
13-17 \text { in Household }\end{array}$ & $\begin{array}{r}2.7 \\
(2.7)\end{array}$ & $\begin{array}{l}15.0 * \\
(7.6)\end{array}$ & $\begin{array}{l}12.3^{* *} \\
(2.5)\end{array}$ & $\begin{array}{r}8.4 \\
(5.9)\end{array}$ \\
\hline
\end{tabular}


Table 4: Determinants of Child Wake-Up and Bed Times (continued)

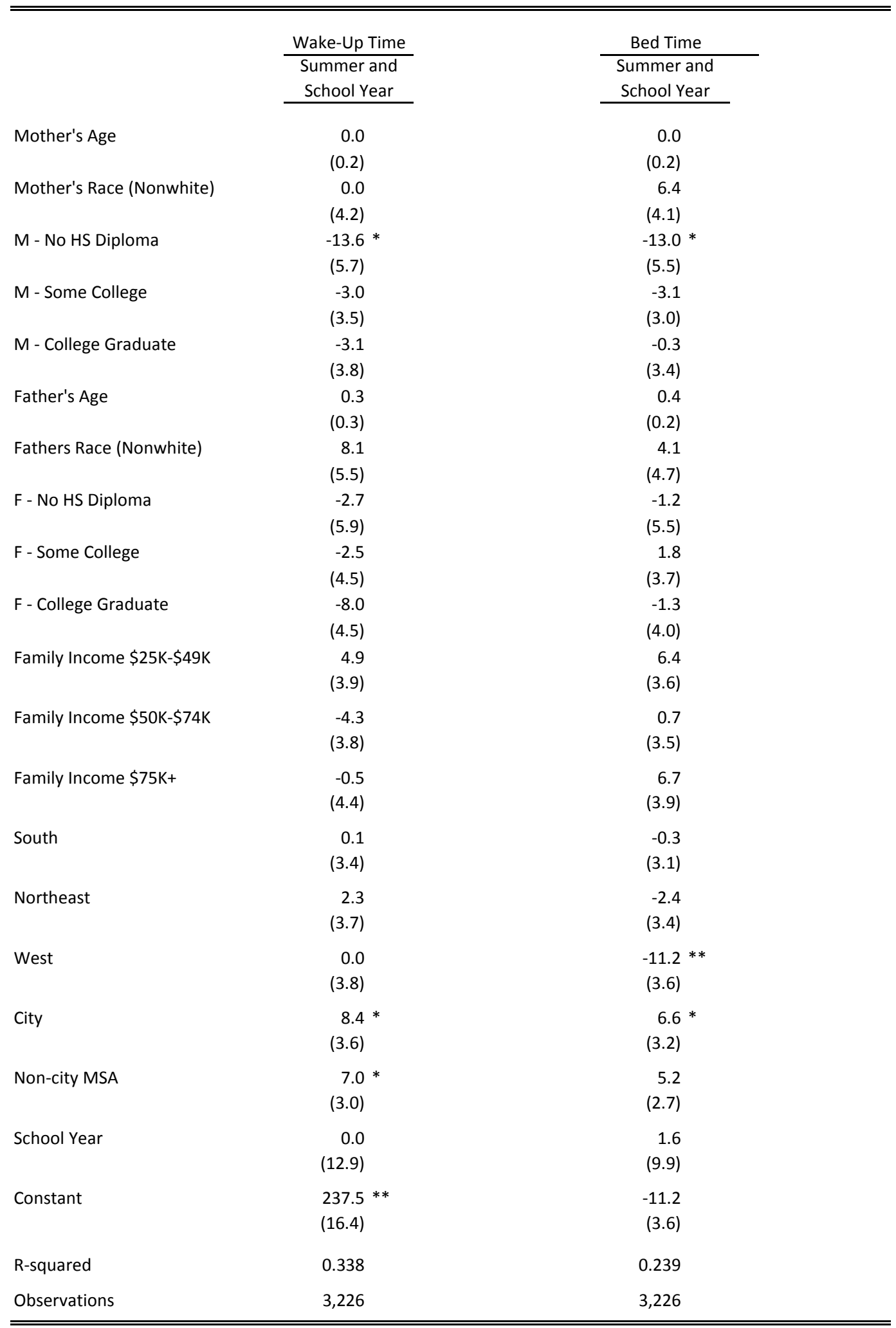

The Summer and School Year coefficients for the main variables of interest were estimated jointly for the wake-up and bedtime equations (there were 2,436 School Year observations and 790 Summer observations), but the control variables were constrained to have common effects. Details about the estimation are in footnote 15. Standard errors are in parentheses.

* Significant at the $5 \%$ level. ${ }^{* *}$ Significant at the $1 \%$ level. 
Table 5: Predicted Wake-Up and Bed Times, and Implied Total Sleep Time

\begin{tabular}{|c|c|c|c|c|c|c|c|c|c|}
\hline & \multicolumn{3}{|c|}{ Wake-up Time } & \multicolumn{3}{|c|}{ Bed Time } & \multicolumn{3}{|c|}{ Total Sleep Time } \\
\hline School Year - Mother Employed FT & $\begin{array}{c}6-8 \\
\text { Year-olds } \\
\end{array}$ & $\begin{array}{c}9-10 \\
\text { Year-olds } \\
\end{array}$ & $\begin{array}{c}11-12 \\
\text { Year-olds }\end{array}$ & $\begin{array}{c}6-8 \\
\text { Year-olds } \\
\end{array}$ & $\begin{array}{c}9-10 \\
\text { Year-olds }\end{array}$ & $\begin{array}{c}11-12 \\
\text { Year-olds }\end{array}$ & $\begin{array}{c}6-8 \\
\text { Year-olds }\end{array}$ & $\begin{array}{c}9-10 \\
\text { Year-olds } \\
\end{array}$ & $\begin{array}{c}11-12 \\
\text { Year-olds }\end{array}$ \\
\hline (1) Non-school day (night) \& Nonwork Day & $\begin{array}{r}8.25 \\
(0.13)\end{array}$ & $\begin{array}{r}8.29 \\
(0.13)\end{array}$ & $\begin{array}{r}8.22 \\
(0.13)\end{array}$ & $\begin{array}{l}21.78 \\
(0.14)\end{array}$ & $\begin{array}{l}21.92 \\
(0.13)\end{array}$ & $\begin{array}{l}22.31 \\
(0.13)\end{array}$ & $\begin{array}{l}10.48 \\
(0.19)\end{array}$ & $\begin{array}{l}10.37 \\
(0.19)\end{array}$ & $\begin{array}{r}9.90 \\
(0.18)\end{array}$ \\
\hline (2) School day (night) \& Nonwork day & $\begin{array}{r}7.04 \\
(0.14)\end{array}$ & $\begin{array}{r}7.07 \\
(0.15)\end{array}$ & $\begin{array}{r}7.00 \\
(0.14)\end{array}$ & $\begin{array}{l}21.11 \\
(0.13)\end{array}$ & $\begin{array}{l}21.25 \\
(0.12)\end{array}$ & $\begin{array}{l}21.65 \\
(0.11)\end{array}$ & $\begin{array}{r}9.93 \\
(0.19)\end{array}$ & $\begin{array}{r}9.81 \\
(0.19)\end{array}$ & $\begin{array}{r}9.35 \\
(0.18)\end{array}$ \\
\hline (3) School day (night) \& Workday & $\begin{array}{r}6.79 \\
(0.11)\end{array}$ & $\begin{array}{r}6.86 \\
(0.11)\end{array}$ & $\begin{array}{r}6.75 \\
(0.12)\end{array}$ & $\begin{array}{l}21.04 \\
(0.11)\end{array}$ & $\begin{array}{l}21.19 \\
(0.11)\end{array}$ & $\begin{array}{l}21.58 \\
(0.11)\end{array}$ & $\begin{array}{r}9.75 \\
(0.16)\end{array}$ & $\begin{array}{r}9.67 \\
(0.16)\end{array}$ & $\begin{array}{r}9.17 \\
(0.16)\end{array}$ \\
\hline \multicolumn{10}{|l|}{ School Year - Mother Not Employed } \\
\hline (4) Non-school day (night) & $\begin{array}{r}8.32 \\
(0.15)\end{array}$ & $\begin{array}{r}8.23 \\
(0.14)\end{array}$ & $\begin{array}{r}8.21 \\
(0.14)\end{array}$ & $\begin{array}{l}21.81 \\
(0.15)\end{array}$ & $\begin{array}{l}22.00 \\
(0.14)\end{array}$ & $\begin{array}{l}22.31 \\
(0.14)\end{array}$ & $\begin{array}{l}10.51 \\
(0.21)\end{array}$ & $\begin{array}{l}10.23 \\
(0.20)\end{array}$ & $\begin{array}{r}9.91 \\
(0.20)\end{array}$ \\
\hline (5) School day (night) & $\begin{array}{r}7.11 \\
(0.14)\end{array}$ & $\begin{array}{r}7.01 \\
(0.14)\end{array}$ & $\begin{array}{r}7.04 \\
(0.14)\end{array}$ & $\begin{array}{l}21.15 \\
(0.13)\end{array}$ & $\begin{array}{l}21.34 \\
(0.12)\end{array}$ & $\begin{array}{l}21.67 \\
(0.12)\end{array}$ & $\begin{array}{r}9.95 \\
(0.19)\end{array}$ & $\begin{array}{r}9.67 \\
(0.18)\end{array}$ & $\begin{array}{r}9.36 \\
(0.18)\end{array}$ \\
\hline \multicolumn{10}{|l|}{ Summer - Mother Employed FT } \\
\hline (6) Nonwork day & $\begin{array}{r}8.05 \\
(0.24)\end{array}$ & $\begin{array}{r}8.37 \\
(0.26)\end{array}$ & $\begin{array}{r}8.72 \\
(0.22)\end{array}$ & $\begin{array}{l}21.65 \\
(0.18)\end{array}$ & $\begin{array}{l}21.93 \\
(0.19)\end{array}$ & $\begin{array}{l}22.40 \\
(0.19)\end{array}$ & $\begin{array}{l}10.40 \\
(0.30)\end{array}$ & $\begin{array}{l}10.44 \\
(0.32)\end{array}$ & $\begin{array}{l}10.31 \\
(0.29)\end{array}$ \\
\hline (7) Work Day & $\begin{array}{r}7.47 \\
(0.21)\end{array}$ & $\begin{array}{r}7.78 \\
(0.25)\end{array}$ & $\begin{array}{r}8.13 \\
(0.24)\end{array}$ & $\begin{array}{l}21.65 \\
(0.17)\end{array}$ & $\begin{array}{l}21.93 \\
(0.17)\end{array}$ & $\begin{array}{l}22.40 \\
(0.23)\end{array}$ & $\begin{array}{r}9.82 \\
(0.27)\end{array}$ & $\begin{array}{r}9.86 \\
(0.30)\end{array}$ & $\begin{array}{r}9.73 \\
(0.33)\end{array}$ \\
\hline $\begin{array}{l}\text { Summer - Mother Not Employed } \\
\text { (8) All days }\end{array}$ & $\begin{array}{r}8.34 \\
(0.23)\end{array}$ & $\begin{array}{r}8.53 \\
(0.24)\end{array}$ & $\begin{array}{r}8.48 \\
(0.22)\end{array}$ & $\begin{array}{l}21.60 \\
(0.16)\end{array}$ & $\begin{array}{l}22.22 \\
(0.18)\end{array}$ & $\begin{array}{l}22.36 \\
(0.20)\end{array}$ & $\begin{array}{l}10.74 \\
(0.28)\end{array}$ & $\begin{array}{l}10.31 \\
(0.30)\end{array}$ & $\begin{array}{l}10.12 \\
(0.29)\end{array}$ \\
\hline \multicolumn{10}{|l|}{ Differences } \\
\hline (1) - (4) & $\begin{array}{r}-0.07 \\
(0.20)\end{array}$ & $\begin{array}{r}0.06 \\
(0.20)\end{array}$ & $\begin{array}{r}0.00 \\
(0.19)\end{array}$ & $\begin{array}{r}-0.04 \\
(0.20)\end{array}$ & $\begin{array}{r}-0.08 \\
(0.19)\end{array}$ & $\begin{array}{r}0.01 \\
(0.20)\end{array}$ & $\begin{array}{r}-0.03 \\
(0.28)\end{array}$ & $\begin{array}{r}0.14 \\
(0.27)\end{array}$ & $\begin{array}{r}0.00 \\
(0.27)\end{array}$ \\
\hline (1) - (6) & $\begin{array}{r}0.20 \\
(0.27)\end{array}$ & $\begin{array}{r}-0.08 \\
(0.29)\end{array}$ & $\begin{array}{l}-0.50 * \\
(0.25)\end{array}$ & $\begin{array}{r}0.13 \\
(0.22)\end{array}$ & $\begin{array}{r}-0.01 \\
(0.23)\end{array}$ & $\begin{array}{r}-0.09 \\
(0.23)\end{array}$ & $\begin{array}{r}0.08 \\
(0.35)\end{array}$ & $\begin{array}{r}-0.07 \\
(0.37)\end{array}$ & $\begin{array}{r}-0.41 \\
(0.34)\end{array}$ \\
\hline (1) - (8) & $\begin{array}{r}-0.09 \\
(0.26)\end{array}$ & $\begin{array}{r}-0.24 \\
(0.27)\end{array}$ & $\begin{array}{r}-0.27 \\
(0.25)\end{array}$ & $\begin{array}{r}0.18 \\
(0.21)\end{array}$ & $\begin{array}{r}-0.30 \\
(0.22)\end{array}$ & $\begin{array}{l}-0.05 \\
(0.24)\end{array}$ & $\begin{array}{r}-0.26 \\
(0.33)\end{array}$ & $\begin{array}{r}0.06 \\
(0.35)\end{array}$ & $\begin{array}{r}-0.22 \\
(0.35)\end{array}$ \\
\hline (2) - (1) & $\begin{array}{l}-1.22 * * \\
(0.19)\end{array}$ & $\begin{array}{l}-1.22 * * \\
(0.20)\end{array}$ & $\begin{array}{l}-1.22 * * \\
(0.19)\end{array}$ & $\begin{array}{l}-0.66^{* *} \\
(0.19)\end{array}$ & $\begin{array}{l}-0.66 * * \\
(0.18)\end{array}$ & $\begin{array}{l}-0.66 * * \\
(0.18)\end{array}$ & $\begin{array}{l}-0.55 * \\
(0.27)\end{array}$ & $\begin{array}{l}-0.55 * \\
(0.27)\end{array}$ & $\begin{array}{l}-0.55^{*} \\
(0.26)\end{array}$ \\
\hline (3) - (2) & $\begin{array}{r}-0.25 \\
(0.18)\end{array}$ & $\begin{array}{r}-0.21 \\
(0.19)\end{array}$ & $\begin{array}{r}-0.25 \\
(0.18)\end{array}$ & $\begin{array}{r}-0.07 \\
(0.17)\end{array}$ & $\begin{array}{r}-0.07 \\
(0.16)\end{array}$ & $\begin{array}{r}-0.07 \\
(0.16)\end{array}$ & $\begin{array}{r}-0.18 \\
(0.25)\end{array}$ & $\begin{array}{r}-0.14 \\
(0.25)\end{array}$ & $\begin{array}{r}-0.18 \\
(0.24)\end{array}$ \\
\hline (3) - (7) & $\begin{array}{l}-0.688^{* *} \\
(0.24)\end{array}$ & $\begin{array}{l}-0.92 * * \\
(0.28)\end{array}$ & $\begin{array}{l}-1.38 * * \\
(0.27)\end{array}$ & $\begin{array}{l}-0.60 * * \\
(0.20)\end{array}$ & $\begin{array}{l}-0.74^{* *} \\
(0.20)\end{array}$ & $\begin{array}{l}-0.82 * * \\
(0.25)\end{array}$ & $\begin{array}{l}-0.08 \\
(0.31)\end{array}$ & $\begin{array}{l}-0.18 \\
(0.34)\end{array}$ & $\begin{array}{l}-0.56 \\
(0.37)\end{array}$ \\
\hline (7) - (6) & $\begin{array}{r}-0.59 \\
(0.32)\end{array}$ & $\begin{array}{r}-0.59 \\
(0.36)\end{array}$ & $\begin{array}{r}-0.59 \\
(0.33)\end{array}$ & $\begin{array}{r}-0.01 \\
(0.25)\end{array}$ & $\begin{array}{r}-0.01 \\
(0.26)\end{array}$ & $\begin{array}{r}-0.01 \\
(0.30)\end{array}$ & $\begin{array}{r}-0.58 \\
(0.40)\end{array}$ & $\begin{array}{r}-0.58 \\
(0.44)\end{array}$ & $\begin{array}{c}-0.58 \\
(0.44)\end{array}$ \\
\hline
\end{tabular}

Note: Standard errors are in parentheses. ${ }^{* *}$ Statistically significant at the $1 \%$ level. $\quad *$ Statistically significant at the $5 \%$ level. 